\title{
ПОЛЕМІКА
}

\section{Владимир Демьянов}

\section{ДОГМАТИЗМ FOREVER, НИЧЕГО НОВОГО}

«Sacrificum intellectus, або ж Нове обличчя догматизму» [Богачев, 2013] (далее только номер страницы в круглых скобках). Это сочинение Андрея Леонидовича Богачёва всецело посвящёно мне, Демьянову Владимиру Александровичу, родившемуся в Киеве в 1949 г., в 1977 г. окончившему философский факультет Киевского государственного университета имени Т. Шевченко, и с 1987 г. преподающему в этом самом университете. Чтобы интересующиеся, благо такие найдутся, не обременялись обращением к латинскому словарю, переведу заглавие произведения удобопонятно: «Заклание разума, или Новое обличье (лик, лицо) догматизма». Это я, Демьянов Владимир Александрович. Это я, новое обличье догматизма. Это я принёс в жертву свой разум. В жертву догматизму. И пребываю в невежестве. И догматизме.

Право же, я писал свои «Идеи к метафизике православной догматики» вовсе не для того, чтобы привлечь к себе внимание университетского философа, писал для христиан, в христианском журнале, мне за державу было обидно, за философию, за философов, которые усердно пришивают гламурные пуговицы, а за костюм не отвечают. Да и сочинять нынче что-либо академическое всерьёз как-то безнадёжно. Ну, напечатают тобою выстраданное тиражом в сто экземпляров, прочтут человек пятьшесть, остальные развернут малотиражный сборник только для того, чтобы установить, на каких страницах $u x$ статья опубликована (для отчёта по науке). Это всё равно, что бросать гранаты в болото. Всплывёт пара головастиков. И всё! Но, надо же, всплыл некто на удивление увесистый: Андрей Леонидович Богачёв, родился в 1967 г. от Рождества Христова в Полтаве, в 1992 г. от Рождества Христова закончил философский факультет Киевского национального университета им. Т. Г. Шевченко, с 1994 г. от Рождества Христова там же и преподаёт. Как говорят рыбаки, «крупняк» попался. Нашёлся-таки Аристарх, который решил «разобраться с таможней». «Sacrificum intellectus» произвела такое впечатление, что на меня наехала таблица умножения на гусеничном ходу, вся в броне. Что-то наподобие брошюры Фридриха Энгельса «Людвиг Фейербах и конец классической немецкой философии». С упованием на то, что я-то и есть последний из могикан. Как только жив остался? Или уже пора объявлять о сборе средств на сооружение монумента?

А. Богачёв немало озабочен зловредностью моего влияния на неокрепшие украинские умы. Каковое, кажется, намерен упредить (с. 194, 195). Налицо - охранительство и, соответственно, заидеологизированность. И желание обличить. Прили-

(C) В. Демьянов, 2014 
чествующая такому занятию позиция - предстать святее «тата римського», защитить Европу от замшелого «византийства».

Право же, вовсе не жажду я истребить европейскую философию. Речь идёт о её ограниченности, о всего лишь «критике», которая для неё не внове. Все всех издавна критикуют. Ещё Ксенофан Колофонский написал труд «Против всех(!) философов». Зря Андрей Леонидович всполошился. Владимир Сергеевич Соловьёв обличение «кризиса западной философии» (а кто же не обвинял в кризисе и «европейские науки» и даже «европейское человечество», разве что ленивый?) начинает заявлением: «В основу этой книги легло то убеждение, что философия в смысле отвлечённого, исключительно теоретического познания окончила своё развитие и перешла безвозвратно в мир прошедшего» (здесь Соловьёв погорячился, жив курилка. Aвm.). Но с его стороны это не голое критиканство, не критикантство: «...Признавая отвлечённо-философское развитие законченным, я не считаю его, однако, бесплодным, а признаю, напротив, что оно привело к известным положительным результатам, определение которых и составляет главную задачу этой книги» [Соловьёв, 1914: с. 27]. «Известные положительные результаты» христианской мыслью плодотворно усвоены.

Поскольку, в устном порядке, я призван автором к ответу, смею надеяться (а иначе во всём нижеследующем нет никакого смысла), в дальнейших рассуждениях позволительно исходить из предположения, что «Sacrificum intellectus» не абсолютно всем и не абсолютно достоверно доказала, что со мной, после заклания моего разума, и говорить-то не о чем. Может быть, всё же, хотя бы двое или трое соберутся во имя моё.

Из контекста «Sacrificum intellectus» для меня вытекают две задачи. С одной стороны, это защита идеи христианской метафизики как позволительного образа философствования, имеющего под собой вразумительные философские основания, a с другой, так уж выходит, - даже и защита самого христианства. Первому заданию я и посвящу почти всё нижеследующее. Что же касается защиты христианской веры перед язычниками, так над этим много потрудились Отцы Церкви первых веков, на муки ради того шли. Вопрос этот сугубо богословский, и не мне бы его решать. Да и аргументы Андрея Леонидовича мало чем отличаются от инвектив ещё тогдашних язычников. Впрочем, апологетическая тематика не стала архаикой, полемика с христианской мыслью всё вновь и вновь актуализируется, и на контраргументы приходится отвечать, труды по апологетике христианства, может быть, пишутся и сегодня. Я же позволю себе лишь процитировать по этому поводу сравнительно недавнее сочинение. Мне кажется, оно весьма споспешествует пониманию сути затеявшейся полемики. Увы, цитата будет обширной: «Самая большая опасность, которой иногда подвергаются неопытные апологеты христианства, заключается в соблазне критикой, ради которой забывается положительная задача построения христианского мировоззрения, - предостерегал И. М. Андреев, профессор Джорданвилльской семинарии. - Наука апологетика, являющаяся основой и введением в богословие, не должна размениваться на мелочную критику частных обывательских заблуждений, обличение которых принадлежит по преимуществу пастырской деятельности, а должна сосредотачиваться на критике основ целых систем мировоззрений, враждебных религии вообще и христианству в особенности. 
Окончательной целью православной апологетики (основного апологетического богословия) является построение несокрушимого фундамента целостного церковноправославного христианского мировоззрения, защита его основ от нападок философской и научной критики и, одновременно с этим, разрушение основ всех противных христианству мировоззрений» [Андреев, 2006: с. 10]. Каюсь, ради «окончательной цели» потрудился пока недостаточно. Но мне уже и за критику «частных обывательских заблуждений» изрядно досталось.

Наряду с понятием онтологической истины (нераздельная неслиянность знания и бытия), есть место и сопоставимой с ней лжи. Это сознательное расторжение знания и бытия. Младоевропеец знает, что он не европеец, но тем более усердствует убедить окружающих в противном (в конце концов, и сам поверит). «...Есть люди, пишет митрополит Антоний Сурожский, - которые так привыкают играть определённую роль в жизни, что они потом себя и сыскать не могут. Они настолько едины стали с тем образом, который себе выдумали, что они себя настоящего никогда не встречают. Бог где-то насквозь видит настоящего Ивана, Петра, Марию, а они сами больше не могут» [Антоний, 2009: с. 230].

Некогда Михаил Жванецкий посоветовал вести дискуссию следующим образом: не слушать оппонента, а внимательно его разглядывать, в самый острый момент спросить паспорт, сверить прописку, сличить фотографию. Итог понятен: что вообще может нам сказать человек без прописки, да ещё с таким носом! Другой вариант - спор Паниковского и Шуры Балаганова с бесконечно повторяемым: «А ты кто такой?!» «Sacrificum intellectus» провоцирует именно на это. Акцент на онтологическом приоритете личностного образа бытия, действительно присутствующий в моих рассуждениях, вовсе не был призывом «перейти на личности». Имелся в виду тип философствования, обусловленный характером фундаментальных верований.

В моих «Идеях» я попытался проиллюстрировать отличие субъекта от личности, а тем самым и от человека (ибо человек ведь не может не быть личностью), примером профессиональной деятельности футболиста, который обязан, по правилам игры, неампутированные руки свои всё же из своих действий исключить. Абстрагироваться от способности оперировать имеющимися у него руками. И фигурировать, как практически-действенная абстракция. На моего оппонента такой пример впечатления не произвёл, по-видимому. Для вящей убедительности рискну прибегнуть к менее изящной иллюстрации (да простит меня возможный читатель, но иначе, кажется, не объяснить). Так вот, чтобы гинеколог исполнил свой профессиональный долг, он должен, в полном соответствии с изначальной идеей Гуссерля, отрешиться от «наивной естественной установки» на свой предмет. Тем самым, редуцировав сам себя к модусу субъекта профессиональной деятельности (как таковой, он и конституируется исключительно предметом и сам, повторюсь, выступает в этом амплуа самодействующей абстракцией), только так он и оказывается способен надлежащим образом выполнять свои должностные обязанности. Служить гинекологом. Но, отставив «естественную» установку, к какой же это установке мы перейдём? Естественно, к искусственной (не сверхъестественной, но и не противоестественной), исключающей всеполноту человеческого бытия, ограничивающей полнокровное бытие «качествованием», т.е. пребыванием в той или иной определённости, ограниченности. Так человек практически-действенно обращает себя в 
конструкт, и таковы реалии нашего социального бытия, на каждом шагу того неумолимо требующие. Но субъектом того или иного вида деятельности человек способен лишь бывать. На время исполнения профессиональных обязанностей, социальной роли. Думаю, как человек, вне своей профессии, тот же гинеколог способен повести себя по-иному.

Эпифеноменальность мышления субъекта достаточно выразительно иллюстрирует и тот язык, которым он мыслит. Естественный язык обладает всеполнотой возможностей, язык искусственный - язык науки, философии и права - использует возможности понятия, понятия унивокативного. А понятие такого рода способно выразить лишь одинаковое во всех индивидах, от индивидуальности положено абстрагироваться. Такова техника этой «способности суждения». Понятийный, искусственный язык не вмещает пластичности, интонационности, лексической экспрессивности, металогичности языка естественного. Оттого-то, наверное, и бесцветны бывают сугубо философские тексты.

Сантехнику, в его профессиональном взаимодействии с водопроводом и канализацией, вполне позволительно, да и естественно, забыть, кто он есть и зачем он есть как человек. Зачем? - Да вот же, чтобы профессионально краны чинить! «Вчилися, бамагу маєм!» Умелого владения предметом довольно и с преподавателя той или иной «философской дисциплины». Но вот достаточно ли этого, чтобы чувствовать себя вправе именоваться философом? Некогда мне преподали урок студентыфизики. На дворе стоял мглистый рассвет перестройки. Студенты бунтовали. Потогдашнему, конечно: «Почему Вы преподаёте нам именно марксизм?» Объяснять, что такова учебная программа, не стал. Попытался предложить альтернативы, но философский плюрализм очень быстро их утомил. Захотелось «правильной» философии, одной для всех. На последнем в семестре занятии студенты меня просто ошарашили, обвинив: «Вы старательно исполняли роль преподавателя, а вот учителем быть избегали». Пришлось призадуматься...

В математике не без пользы используется приём доказательства от противного. Допустим, что противоположный нашему пониманию тезис истинен. Что из этого воспоследует? Вот если повлечёт за собой абсурд, тогда ясно, что ложны исследуемые в качестве исходных принципов положения. В философии есть нечто подобное, и это условие возможности имманентной критики. Противопоставлять же своё мнение, заведомо противоположное иному, малопродуктивно. Ничего, кроме демонстрации враждебности, это не даёт.

Ну что стоит предположить, будто истина со Христом, а не с автором «Sacrificum intellectus»? Ну, просто ради «математического» любопытства? Хоть на минуту? Ну хоть «как если бы» (als ob, по Канту). Тогда придётся констатировать, что автор «Sacrificum intellectus» (Андрей Леонидович Богачёв, 1967 года рождения от Рождества Христова), знаком с христианским вероучением разве что по лекциям кафедры научного атеизма (хотя и нашего, не худшего в этой стране, университета), ибо к такому мысленному эксперименту вряд ли пригоден. Всё в его статье дышит уверенностью в том, что истина с ним, с Андреем Леонидовичем Богачёвым (1967 года рождения по Рождеству Христовому), но отнюдь не со Христом. Остаётся надеяться, что когда-нибудь люди опомнятся и поймут, наконец, чьё Рождество стоит праздновать, а чьё не стоит даже и вспоминать «европейскому человечеству». 
«Sacrificum intellectus» немало посвящена обличению тайных моих упований на учреждение земного рая на началах патернализма и коллективизма (с. 199). И потому я, оказывается, сам того не подозревая, - большевик. Подпольный. Имплицитный. Генетический. И эрудиция моя почерпнута из марксистских учебников.

Всё как-то недосуг было, да и лень-матушка, но уж пора на такие «закыды» ответить. И повод удобный. Невежеством и мракобесием марксизм представляется умам, инфицированным идеологической коньюнктурой. «Ганьба!», и всё тут. Между тем, марксизм есть законное дитя европейского (не азиатского и не африканского) Просвещения. Главная идея просветителей - устроение общества на началах разума, a не по рецептам отягощённых религиозными предрассудками предков. А разумно устроенное общество неминуемо произведёт столь же разумных людей. Пороки исчезнут. Марксизм пошёл дальше, но в том же направлении: надо создать, наконец, науку об обществе и, руководствуясь открытыми ею законами, устроить для человека рай на земле. - Красивая идея. Определённый смысл она имеет. Вот только человек превращается в функцию от социума, и не более. Кант, усматривавший в человеке ни от чего не зависимое «трансцендентальное Я», из этой идеологии выбивается. Если же истину человеческого образа бытия видеть исключительно в его социальной сущности, а она, в конечном счёте, - продукт природной эволюции, Карлу Марксу возразить что-либо вразумительное, существенное попросту нечего. Кантово убеждение в том, что нравственное чувство из природы никак не вывести, придётся отставить.

Что человек - существо социальное, это как бы общее место, не подлежащее обсуждению. Да и какой-нибудь Хабермас или Хоркхаймер Марксу не чета. Ни по масштабу идей, ни по масштабу личности. Чего бы это такого Юрген Хабермас «трансформировал», не будь великого Карла с его историческим материализмом? Да и суть «трансформации» не в восполнении какого-то идейного дефицита, а в милой сердцу редукции. «Форма общения» - изначально конститутивное для марксистской философии понятие, и довольно объёмное. Будучи извлечено из целокупности марксистского образа мысли и латинизировано (вместо Verkehr-communicatio), оно и стало основой «коммуникативной» философии. При этом «коммуникация», сообразно с профессиональным статусом её фундаторов, мыслится по образу и подобию формы общения членов учёного совета.

Марксизм - это европейская классика («европейская ценность»), не в Тюмени его придумали, и по своему теоретическому потенциалу много он превосходит то, что принялись, все как один, как по взмаху дирижёрской палочки, исповедовать наши младоевропейцы и младоукраинцы: «Когда объявили прогресс, так Тарелкин пошёл впереди прогресса!» (Сухово-Кобылин А. B. «Смерть Тарелкина»).

Марксизм есть субстанциализм и, что главное, эссенциализм. Он, по сути, завершает «усиологию» Аристотеля. Стагирит совершенно гениально, в духе своей эпохи, исследовал истину вещи. И усматривал её в сущиности, т.е. в «стольности», которая одинакова во всяком столе. В Новое время философский интерес сосредоточился уже не на «вещи протяжённой» res extensa), а на «вещи мыслящей» (res cogitans). Тому способствовала Реформация, это она во второй раз, после Солона, эмансипировала индивида от рода, довершила эмансипацию, только на сей раз «род» не «фила» - это церковь, церковная община. Но парадигмой, «общим знаменателем» осталось то же самое: вещь! Свой «вещмешок» эта традиция не бросит! И 
совершенно ретроградно язычески-догматическое умствование устремилось разыскивать одинаковое во всех «вещах», но уже не «протяжённых», а «мыслящих». С той же старательностью, с которой Аристотель во всех домах усердствовал найти единую для них «домность». И усматривал её. Но только он - в сущности, а новоевропейское мышление - в субъекте. «Субъект» есть то, что одинаково во всех Иванах-да-Марьях. «Субъект» есть второе пришествие «сущности». Иммануил Кант эти старания усовершил: «трансцендентальный субъект» - это для всех веков и народов и для всех «разумных существ», сколько их ни есть. Кстати, довершил и Аристотелев гилеморфизм, но только гносеологически: носитель формы - субъект, а поставщик «материи опыта» (естественно, лишь возможности формы) - объект, и затаившаяся в нём «вещь-в-себе», лишённая протяжённости. Опять-таки «форма» и «материя», но уже не в вещи - в суждении. Ничего принципиально нового в гносеологической интерпретации гилеморфизма не просматривается. Завершение аристотелизма, кто бы что по этому поводу ни думал. Хотя сам «беспокойный старик Иммануил» в своём деянии усматривал коперниканскую революцию. Правда, оппоненты говорили о «птолемеевской контрреволюции».

Субстанциализм-эссенциализм в его идеалистическом варианте окончательно оформил Гегель. На склоне лет он признался, что главной его задачей было соединить понятия субстанции и субъекта. И много в том преуспел. Получилось как бы «живое», саморазвивающееся и саморозмножающееся понятие. Но жизнь, увы, унивокативным понятием не выразима. Ф.Энгельс попытался: «Жизнь есть способ существования белковых тел!» - такую выдал дефиницию. Не заметил только, что под неё подпадает и колбаса...

С субстаниией, особенно после Спинозы, связывают прерогативу самобытийствовать, с субъектом - равнотождественность всех индивидов и - соответственно, в юридическом эквиваленте, - равноправие. Карл Маркс, надо отдать ему должное, это учуял и заметил: точка зрения всей «прежней» (естественно, «домарксистской») философии - гражданское общество. Но, увы, пребывал он в той же парадигме субъектности и видел исход в чаемом им «обобществившемся человечестве». Действительный человек, личность, конституируется и «сущностью», единой для всех людей, и максимально возможной в сущем индивидуальностью, отличающей всякого индивида от всего сущего и от всех людей, - уникальностью. Обе составляющие равно конститутивны. Игнорируя сингулярность, мы получаем «субъекта». Со всеми вытекающими отсюда последствиями. Дабы избежать хаоса, в социуме уникальность ипостаси подвергается релятивизации, она становится «объектом», «предметом», «персоной» - в этом трагедия личности [см. Зізіулас, 2005: с. 48]. Право же, не стоит подозревать великого, всё-таки, философа в злонамеренности. Но на всякого мудреца довольно простоты.

Автор «Sacrificum intellectus», уж не знаю кем (лишь догадываюсь), осчастливлен способностью тайноведения. Умения читать в сердцах. Он знает, что на самом деле в Бога я не верю. Что я чаю устроения счастья человечества без Бога на началах патернализма и коллективизма. Мне кажется, ни в одном из своих текстов поводов для умозаключений о моём неверии я не подавал, и от Христа не отрекался. Он говорил: кто Меня постыдится, того и Я постыжусь. А мне бы этого не хотелось.

Кто-то из Отцов Церкви заметил, что есть много людей, которые сами в Бога не верят, но этого им мало, их чрезвычайно раздражает, что кто-то верит. Психология 
такого неприятия, пожалуй, коренится в следующем. Понимая себя как продукт природы, вряд ли кто всерьёз разобидится на несправедливость распределения дарованных ею талантов. С природы не спросишь: с какой это стати, за что это не уделён мне гений Моцарта или Ньютона? Природа творит через случайность. А вот предъявлять такие претензии Творцу представляется возможным. Но к сему есть предостережение апостола Павла: «По данной мне благодати, всякому из вас говорю: не думайте о себе более, нежели должно думать; но думайте скромно, по мере веры, какую каждому Бог уделил» (Рим. 12, 3). Естественно, с этим неравенством в распределении даров Господних демократически настроенному разуму согласиться не по силам. Трудно принять в разумение свободу Дарующего, так и хочется продиагностировать зубы дарёного коня. На то и притча Христова: хозяин виноградника всем работникам заплатил за их труд одинаково - и тем, кто трудился с самого утра, и тем, кто пришёл в последний час. В ответ на возмущение работников первого часа им было сказано: вы оговоренную плату получили, и не волен ли я платить остальным по моему разумению?

Хотя бы поверхностное знакомство с учением Христа позволяет понять, что надежд на торжество социального прогресса, на учреждение земного рая оно не подаёт. Джироламо Савонарола попытался христианский идеал в отдельно взятом городе установить, кончилось тем, что пришлось в огонь пойти и сгореть в нём. Откровение Иоанна Богослова (Апокалипсис) предрекает пришествие Антихриста, воцарение его и горькие бедствия для отпавшего от Христа человечества. И в этом контексте явленность orbi et urbi (ладно уж, ради вящего понимания латынь употребим) «Sacrificum intellectus» позволю себе понимать в качестве одного из симптомов.

Что касается патернализма. «Почитай отца твоего и матерь твою, как повелел тебе Господь, Бог твой, чтобы продлились дни твои...» (Втор. 5, 16). Чти отца и мать - это не проповедь «патернализма», который, как я понимаю, автор «Sacrificum intellectus», сообразно своему разумению, мыслит в категориях господства и подчинения. Чтить - вовсе не значит беспрекословно подчиняться власти отца или матери. Заповедь эта преподана для того лишь, чтобы человек не выпал из человеческого образа бытия, чтобы отличал отца от товарища, чтобы не уподобился скоту, который не то что чтить - знать не знает ни отца, ни матери. Заповедь эта уберегает от утраты человеческого достоинства. Скот, возмужав до половой зрелости, в маме родной, в сестре, в дочери ничего, кроме более-менее подходящей самки, узреть не способен. Не ведает греха. Да и откуда бы ему знать? Самозаконодательствовать не научился, Канта не читал. Впрочем, кажется, европейский гуманизм скоро и инцест узаконит. Почему бы и нет? Ведь Содом и Гоморра уже в законе? Библию, очищенную от соответствующих инвектив, уже издали. Для подобающего «сообщества коммуникации». Со временем найдут «учёные» ген, который за всё это ответствен, да и снимут тем самым грех с субъекта. Ну, гены ему такие достались, что ж поделать, он не виноват, природа... Ломброзо придётся вспомнить.

Что касается коллективизма. «Где соберутся двое или трое во имя Моё, там и Я с вами». Эта заповедь Господня вовсе не предвестие коллективизма в понимании автора «Sacrificum intellectus». Отношения господства-подчинения здесь не предполагаются, «двое или трое» собираются воедино не по принуждению и не по мирской нужде. Ну, надо же, Церковь - «коллектив»! Собираются братья и сестры во Христе по своему свободному волеизъявлению. Никто в Церковь ходить не заставляет. И Церковь Господня не есть «коллектив», объединённый «коммуникацией», и не 
«неограниченное сообщество дискурса». Церковь не республика, если уж угодно изъясняться языком субъекта «коммуникативной философии». Церковь - монархия, во главе которой Иисус Христос. Бессменно, без периодического волеизъявления «электората». Навечно. Так согласно католической и православной вере. Обе Церкви не видят пути к Отцу Небесному в обход матери-церкви. У протестантов - да, церкви, по сути, нет. Скорее, «коллектив», «профсоюз верующих». И суждения Канта об «обрядовой церкви» - сугубо сектантские. Но, кажется, моему оппоненту они особенно близки. Почему-то. Здесь есть повод подумать о конфессиональности его атеизма. Александр Лукашенко, не без остроумия, объявил себя «православным атеистом», мой визави, это уж без всякого остроумия, судя по всему, «лютеранский атеист».

За Канта мой оппонент зря обиделся (с. 197, 199, 200), я вполне способен осознать его величие. И даже письменно о том заявил. Но там, где Кантом говорит его сектантство, уж извините, не смолчу. Согласно православному вероучению, дабы войти в истину, необходимо очищение ума от греха и, тем самым, преображение его («метанойя»). Но самое название известного Кантового трактата гласит: «Религия в пределах только разума». Это - кристально-чистая дефиниция понятия «ересь». «Ересь противостоит кафоличности. Еретик возводит в абсолют одну из граней цельного опыта Церкви, таким образом превращая его в нечто одностороннее и ограниченное. Подобная абсолютизация всегда имеет рассудочный характер; она есть результат умозрительного выбора, связанного, как правило, с упрощённым и схематичным восприятием церковной истины» [Яннарас, 1992: с. 46]. Все ереси возникали вследствие благонамеренных, как бы, усилий подогнать догматику христианского вероучения под своё разумение. Но известно ведь, куда ведут такого рода благие намерения...

Ещё, помнится мне, автор «Sacrificum intellectus» изрядно ожесточился супротив моего утверждения, что представитель естествознания обязан верить в вечность, несотворённость и бесконечность Вселенной (с. 197). Что Вселенная, сообразно с метафизикой науки, должна быть признана несотворённой и, следственно, вечной да, продолжаю утверждать. Несотворённый мир не может не быть вечным. Что естествоиспытатель обязан верить: в природе всё происходит само собой, без вмешательства Творца, иначе наука как таковая не получится, также подтверждаю. Но вот, что современная наука доказала, будто Вселенная конечна, позволю себе, вместе с Кантом, усомниться. Дело ведь не в том, «современная» это наука или «несовременная», отстал ли я лично или не отстал от её достижений. Джордано Бруно пошёл на костёр за веру свою в то, что Бог, как существо бесконечное, конечный мир сотворить не мог, а в бесконечной Вселенной должно быть бесконечное количество обитаемых миров. Аргумент, вполне очевидно, теологический, не естественонаучный. Т.e., автор «Sacrificum intellectus», от имени современной науки, инквизиторский приговор с лёгким сердцем подписал бы. Но хотел бы я видеть лицо «беспокойного старика Иммануила» в тот момент, когда Андрей Леонидович Богачёв с глазу на глаз поведал бы ему, что современная наука разрешила-таки первую из его антиномий своими, сугубо научными (современными!), средствами. Старик ведь вершил свой трансцендентализм на века и был «догматически» уверен, что мир в опыте не дан, и в том был прав. А может быть, и остальные антиномии современная наука порешила? А мы с Кантом поотстали? 
Мир в философском его понимании не совпадает по объёму с объёмом опыта хоть всего человечества с его телескопами, хоть с объёмом опыта Андрея Леонидовича. За мир я (вместе с Кантом) спокоен. Меня тревожит другое: как же это философски образованный человек может отождествить видимое в сколь угодно мощные телескопы со всем миром? И принимать теории, построенные на основании данных об эмпирически доступном фрагменте Вселенной, за исчерпывающее знание о мире? Присутствует ли здесь философское понятие о мире? А как с микромиром быть? Онто как далеко простирается? Или уже найдены чаемые «первокирпичики»? Ну, т.е., на такой манер понимать суть дела физику или астроному позволительно - науке свойствен здравый догматизм, и заниматься исследованием собственного вероисповедания ей ни к чему, но как оценить суждения философа, полагающего, что наука способна разрешить Кантовы антиномии? Философия не наука в том смысле, что она лучше науки, что способна исследовать те основания, «верования», из которых всякая наука автоматически исходит, не задаваясь не свойственными ей вопросами.

Автор «Sacrificum intellectus» вступился не только за современную космологию и космогонию, но и за биологию (с. 196), точнее, за дарвинизм. Чарльз Дарвин, надо отдать ему должное, своё «Происхождение видов» выдвинул как гипотезу. И был в этом деле предельно честен. Как человек науки. Не оставляя при этом веру в Бога.

Внедрение в программу среднего образования учебного предмета «биология», картинки в учебнике, иллюстрирующие всеобязательный дарвинизм, превращение обезьяны в человека, неминуемо приводят к тому, что, наряду с преподаваемой теорией, совершенно нерефлектируемо усваиваются, внедряются в подкорку и даже в спинной мозг (намертво!) также те верования, на которых это воззрение покоится. И даже, как видно, ферментируют в сознании получившего философский диплом субъекта. И руководят его дискурсом с автоматизмом безусловного рефлекса, уж совершенно не-критически. Вопреки установке классической философии на способность к тотальному сомнению. Но вот тут-то и запятая. В верованиях, на которых доныне покоится теория эволюции, вызубренная для получения аттестата зрелости, обладателю этого аттестата усомниться уже не по зубам. Хотя и в современной биологии оппозиция дарвинизму имеет место. Не все биологи дарвинисты.

Несколько лет назад, когда студентам философского факультета ещё преподавали биологию, мне пришлось с целым курсом вступить в дискуссию по этому самому вопросу: имеются ли в распоряжении биологов факты, подтверждающие возникновение одного биологического вида из другого. Возмущению студентов (такому же, как и у моего оппонента) не было предела: как это я могу наличие таких фактов отрицать! А следующая лекция у них была как раз по этой самой биологии. Я и посоветовал справиться о спорном вопросе у преподавателя биологии, иного выхода не было. Через неделю, на следующей лекции, студенты извинились передо мной за инцидент и поведали, что преподаватель биологии подтвердил: фактами, удостоверяющими происхождение одного вида из другого, его наука не располагает. Биологи обычно говорят, что видообразование происходило раньше, а сейчас такие факты наблюдать не удаётся. До сих пор восхищаюсь научной честностью и профессионализмом этого человека. И стыжусь, что не потрудился узнать имя.

Что касается искусственного отбора. Как известно, наиболее ревностным сторонником этой технологии был Иван Мичурин. Посредством искусных манипуляций он даже вознамерился так перевоспитать рожь, чтобы она переродилась в пшеницу. Генетики, доказывавшие, что за пределы вида таким усердием выйти не 
удастся, оказались в лагерях, Николая Ивановича Вавилова даже расстреляли. Искусственный отбор позволяет создавать всего лишь новые сорта (если речь идёт о растениях) и породы (это - о животных). Но власти, верившей во всесилие воспитания, и даже намеренной создать с его помощью «нового человека», идеи Мичурина были ближе, а генетика упорно сему противоречила.

Приручение волка, увенчавшееся возникновением собаки (с. 196), с таким знанием дела описанное моим оппонентом (с чужих, правда, слов), никакой не факт. Фактом является всего лишь то, что есть волк и есть собака. Попытка связать эти факты обязывает к различению post hoc и propter hoc, а это уж служебная обязанность и вердикт теоретического («чистого») разума, и напрасно Андрей Леонидович решил, что порождение детки-собаки папой волком есть истина факта. Что post hoc и propter hoc не одно и то же, - об этом можно справиться у Юма. Как и каким образом волк породил собаку - версия биолога, который при этом знаменательном событии не присутствовал, дабы зафиксировать происходящее на его глазах именно как факт. Но ещё более важно: чтобы взяться за сочинение подобных историй, нужно ещё до включения в работу силы воображения уверовать в происхождение видов. Я думаю, моему оппоненту известно, как называется ход мысли, когда доказывают то, из чего на самом деле как уже исходят. Я так понимаю, хочется человеку иметь своим родственником обезьяну (да, собственно, и собаку и волка, если уж эволюционизм прав). Ну что тут поделаешь!

Принципиально важно, между тем, вовсе не опровержение или реабилитация дарвинизма. В конце концов, «божественный промысл не исключает эволюции как элемента развития биологического» [см. Вениамин (Новик)]. Вот слова Библии: «И сказал Бог: да произведёт вода пресмыкающихся, душу живую... да произведёт земля душу живую по роду её, скотов, и гадов, и зверей земных по роду их. И стало так» (Быт. 1, 20 - 24). Порядок творения и порядок эволюции одинаков, противоположно понимание источника творческой силы - то ли «земля» сама, от века обладает креативностью, то ли лишь по слову Творца. И тут своё слово должна сказать вера в то или иное, больше некому. Об этом и говорится в моих «Идеях»: в фундаменте и человеческого способа бытия, и гносеологических бдений субъекта кроются базисные верования, придя в самосознание, верования повышают свой статус становятся верой, которая знает себя. Кстати, Кант «веру» и «верования» различал, по своему, конечно.

B «Sacrificum intellectus» содержится целый сюжет относительно заимствования моих основоположений из чужого опыта (из религиозного опыта Отцов Церкви, не моего, см. с. 201). Если мой оппонент не чужд добросовестной инвентаризации собственных знаний, то, по совершении этой операции, он непременно убедится в том, что и о событиях Троянской войны, и о «красном смещении», и о существовании Антарктиды, о Шпете и Гадамере он «знает» не из своего опыта (если только не включать в объём «опыта» изучение чьих-либо текстов). А заодно должен будет осознать, сколь микроскопична доза его знаний, добытых из собственного опыта. Неловко обращать внимание на это обстоятельство специалиста по «досвіду і сенсу», но я не виноват, он первый начал. Дело ведь даже не в количественном соотношении знаний, полученных через свидетельство, и тех, коими Андрей Леонидович обязан лишь собственной наблюдательности и необыкновенному своему усердию. 
Вопрос этот не для зубоскальства, он принципиально онтологичен. Паук от рождения «знает», как быть пауком. Как пребывать в паучьем модусе бытия. Он обладает для этого исчерпывающей генетической информацией. Человек, народившись, не знает. Человечность в генах не записана. Знать, как быть человеком, младенец научается благодаря дарованной ему от рождения совершенной способности веpuть, верить каждому слову. Верить свидетельству папы и мамы о том, что такое хорошо, и что такое плохо. Слово, без которого нет человека, он получает в дар. Из собственного опыта это знание не получить. Христос призывал: будьте совершенны, как дети. Эллинам сия мудрость представлялась безумием - как же так, дитя совершеннее мужа?! Но человек есть знающее бытие, и, чтобы возрасти в человеческий модус бытия, он должен обладать онтологической прерогативой верить. Что и зафиксировал Климент Александрийский классической формулой: сначала верим, потом знаем. Кстати, именно Кантов принцип трансцендентального единства апперцепции много позже Климента позволил позднейшим философам понять, что «опыт» несводим к данным сенсорики, что в «опыте» участвует весь человек, со всеми его знаниями и верованиями. И появились более вменяемые, чем у Локка, концепции опыта: «трансцендентальный» опыт, «Я-опыт», «опыт бытия», «допредикативный» опыт и т.п. Этого не учитывал позитивизм, возмечтавший о «протокольных суждениях», фиксирующих только факты, без малейшей их интерпретации. Но, как оказалось, эмпирии, мировоззренчески и теоретически не нагруженной, не бывает.

Способность верить есть условие возможности способности знать, трансцендентально предшествует. К этой истине человек (увы, не всякий) по пережитии отрочества, с его отчаянно-безмятежным упованием на всесовершенную способность исключительно собственного рассуждательства (и неверия), возвращается лишь по восхождении «в полноту возраста Христова». Это, очевидно, и имели в виду Отцы Церкви, именуя философию греков «детоводительством ко Христу». Но в отрочестве можно и застрять навеки. И это - судьба языческой философии. Это - философия отроков. Герберт Уэллс как-то отметил: когда мне было пять лет, я думал, что мой отец знает и понимает всё, когда мне исполнилось 15 лет, я решил, что он не понимает ничего, а в 30 лет я осознал, что отец знает нечто такое, чего я ещё не понимаю. Увы, не всем это дано... Нет у субъекта ни отца, ни матери. То есть, у Декарта, конечно же, были папа с мамой. Но философствовать он принялся, как сам себе сын. Почтальон Печкин был уверен, что «мальчики всегда чьи-то бывают». Но нашёлся на его голову «сам свой собственный мальчик» - дядя Фёдор из Простоквашино.

Принципиальное различение полнокровного образа человеческого бытия - личностного - и добровольно-принудительной редукции к субъекту, и, соответственно, к законничеству и унификации, к безличностности, есть, действительно, одна из основных «идей» моих «Идей». «К метафизике православной догматики». Понимание этого онтологического «обстояния» осложняется тем, что всякий человек, вынужденный в социуме редуцировать себя к субъекту какого-либо вида деятельности, хоть к кондуктору в трамвае, хоть к доценту какой-нибудь кафедры, продолжает оставаться личностью. В работе токаря или фрезеровщика его личностное естество ферментирует гомеопатически. Но всё же присутствует. Работа продавца уже требует хотя бы соблюдения приличий, этикета, уже какой-то человечности, ведь не с металлом продавец «общается» - с людьми. Непонимание этой истины сделает его 
работу малоуспешной. Естественно, в исполнении обязанностей преподавателя какой-либо из учебных дисциплин личностное начало ещё более значимо, но и здесь не превышает по важности главное условие - владение предметом. И потому преподавать может всякий, кто знает предмет. Иное дело, что, будучи личностно невоспринят студенческой аудиторией, такой субъект и профессиональные свои обязанности будет исполнять с превеликим трудом. И неэффективно.

Наконец, о главном - о «догматизме».

Догматичен ли Эвклид, «тупо» следующий в выведении «тела» своей геометрии заявленным изначала постулатам её? - Не думаю. Ведь постулаты Эвклидовой геометрии чётко и ясно сформулированы. Эксплицированность исходных основоположений оставляет возможность их пересмотреть, что и позволило впоследствии преодолеть догматизм «Эвклидова ума» и создать несколько неевклидовых геометрий. Между прочим, после этого и перед «априорной», по Канту, математикой восстала гносеологическая проблема: а какова геометрия действительного пространства, Эвклидова она или неэвклидова? Тут уж пришлось обратиться к физике, вывести коэффициент содержания вещества в единице объёма, от которого и зависит эвклидовость/неэвклидовость реального пространства, и решать вопрос не априорно, не математически, апостериорно. Осталось только обследовать всю Вселенную и разделить её массу на объём.

Теперь спрашивается, является ли догматизмом следование сознательно принятым догматам-аксиомам, дабы из них эксплицировать христианскую метафизику? На мой взгляд, ничуть не бывало. Для христианина в этих основоположениях сознательно исповедуемая истина. И принимались они не «слепо», как твердит философский словарь. «Символ веры», например, принимал I Никейский собор с участием 318-ти епископов, учёнейших людей, после длительных дискуссий, текст выверен до «йоты», принят единодушно. Да и все вероопределения всех соборов принимались именно таким образом. Способен ли на что-либо подобное какойнибудь философский конгресс? Хотя бы в согласовании единого текста относительно того, что вообще следует понимать под философией?

Догматизмом одарено мышление, не сознающее тех догм-верований, которымм оно неосознанно (и тем более беспрекословно) следует, с автоматизмом безусловного рефлекса. В языческой философии таковых масса. Осмелюсь утверждать, их носителем является и мой оппонент. Не возьмусь, по крайней мере, в рамках сего опуса, «огласить весь список» этих догм, но одну, и основополагающую для языческого образа философствования, не обличить не вправе. Она - в безмятежной уверенности: истина - в субъекте «філософування», в его способности к истине, в онтологичной истинности субъектно-индивидного модуса бытия. И это не что иное, как самоуверенность и самонадеянность. Вот христианский взгляд на эту догму: «Корень греха, грех в своей метафизической сущности - в самодовольном самообосновании «Я $=Я \gg$. ., это та сила сохранения себя как себя, которая делает личность «само-истуканом», идолом для себя, «объясняет» Я с помощью Я» [Иустин (Попович), 2004: с. 253]. Так - у Канта, отца всех нынешних еретиков: истина есть содержимое субъекта. Априорно. Никто и ничто, кроме имманентной способности «критически мыслить», трансцендентальному субъекту для постижения истины не нужны. А откуда взялась эта «способность»? Не от «другого» ли? Но уже Фихте обнаружил: в «чистом» самосознании трансцендентального субъекта 
«другой» никак не представлен. Отсюда и высокоумные мучения с пресловутой «интерсубъективностью». Условие возможности человеческого образа бытия, нечто изначальное, - «другой» - искусственно превращено в замысловатую проблему, подлежащую «доказательству», догадкам аппрезентации! О, Господи, сколько на эту тему никому не нужных текстов написано! Ну, чем не мазохизм?

Когда Кант, вслед за Юмом, утверждает, что ни одна «вещь» не положена в сущем так, чтобы вследствие этого с необходимостью была положена и другая «вещь», он провозглашает истину вещизма, всей той традиции, которая молча исходит из онтологического приоритета мёртвой вещи, физико-химическоматематической, от этой печки и пляшет. И ведь, действительно, ни другие вещи ей не нужны, ни она им. Но если воззреть, к примеру, хотя бы на растение, догматизм, опрометчивость и ограниченность подобного рода метафизики станут совершенно очевидны. Живому, для его бытия, очень даже нужны другие «вещи». Живое без них попросту немыслимо. Бог христиан - Бог живых, а не мёртвых, Он - Абсолютная Жизнь. И Путь, и Истина, и Жизнь. На этом догмате и упрочена метафизика православной догматики.

Если «субъект» есть то одинаковое, что содержится в каждом человеке, будь то мужчина или женщина, каково же может быть содержание «дискурса» между ними, такими одинаковыми? Что интересного может сообщить один одинаковый неотличимому от него, такому же, как биллиардный шар, одинаковому? Разве что толкнуть, чтобы занять его место (вещь есть то, что занимает место). Мужчина и женщина, слава Богу, весьма различаются. И потому один другому интересны. Как человеки. (Тут, правда, не без европейских новаций.) Но как субъекты - одинаковы. И содержательность общению субъектов может сообщить лишь неодинаковое отношение к какой-нибудь вещи, товару, социальному институту и т.п., чему-нибудь предметному. Тогда один из них, например, продавец, другой - покупатель, один арендатор, другой - арендодатель, один - хозяин, другой - работник, один - химик, другой - ихтиолог. Их взаимоотношения - вещно-предметные. Ничего личного.

Человек конституируется верой, без врождённой способности верить не войти новорожденному в человеческий образ бытия. Так - в онтогенезе, и это факт; филогенез, антропогенез - не факт, гипотеза. Если и есть смысл в гипотезе о «врождённых идеях», так он именно в этом, во врождённой способности верить. Субъект же самоутверждается способностью суждения, одной лишь из не первых человеческих способностей, и, будучи психически здоров, не чужд сомнения в истинности собственных умозаключений. Что философия, в изначально-языческом её статусе, приходит в себя как культура сомнения, я думаю, философски образованному человеку не стоит доказывать. «Знаю, что ничего не знаю» - это акт сомнения. В чём? - Да во всём том, что естественным образом обрёл через веру, через чьё-либо свидетельство. Но отныне оно - «докса» и заведомо, для субъекта, не есть истина. Потому что не моё это. А верю только в моё, в собственную, способность к истине, «способность суждения» о ней.

Прежде чем стать субъектом хоть права, хоть научного познания, хоть философствования, совершенно необходимо состояться человеком. Да и вовсе не обязательно человеку становиться философом. Разве что Ксантиппа в жёны попадётся. Всякая «субъектность»- всего лишь одна из возможностей. Акт предшествует потенции, или, если не латинизировать Аристотеля, действительность предшествует возможности. Это - метафизический факт. 
Философия содержит в себе целый прейскурант суждений об истине. «Гносеологическая» (корреспондентная), «когерентная», «конвенциональная», «прагматическая» и т.п. Все такого рода конщепции истины крупицу истины, вне всякого сомнения, содержат. Но философия не была бы сама собой, если бы не жаждала Истиньl. И самое философское - это дать себе труд задуматься об истинности самой философии. Ведь если что «критикуешь», то уж, несомненно, - с позиции Истины. А иначе и смысла нет во всех твоих умствованиях, разве что «умняка» нагнать для устрашения публики. Так существует ли критерий истины для самой философии?

Начатки понимания единства единого, истинного и благого, можно найти уже у Платона. «Единое, истинное и благое» - трансценденталии бытия, первопринципа, первоначала. Единое, истинное, благое - это нераздельная неслиянность. На том стоит христианская метафизика. В её компетенцию входит разумение альтернативы: либо истина - это $Я$, сам свой собственный, и никто мне в моих суждениях о чём угодно не указ. Либо, всё же, способность к истине мне дарована. И есть Даритель, более истинный, чем моё «Я». Но путь к субъектному образу бытия - это путь редукции, а «редукционизма к Богу быть не может, как не может быть редукции низшего к высшему» [Вениамин (Новик)].

Вся сложность в том, что в способе человеческого разумения бытия ипит, verum, bопит вполне могут фигурировать в своей отдельности. Тринитарная нераздельная неслиянность - атрибут Истины, Триипостасного Бога-Творца, это Он Единый, Истинный и Благой. Творение же, в силу дарованной ему свободы, способно к сепаратизму, к отдельности. Неслиянной. В своей собственной экзистенции человек обязательно переживает и ипит (единство собственного естества), и verum (несомненную истинность собственного бытия), и bопит (благость собственного бытия - порукой тому инстинкт самосохранения). Но, отделившись от самого себя, трансформировавшись в субъекта, человек способен воспринимать всё это как бы по отдельности. И потому, философствуя в автаркии, вполне возможно представлять себе истину этически нейтральной (Бэкон призывал «пытать» природу, чтобы выведать её тайны, но раз уж так, то почему бы и человека не пытать - ради какихлибо утаиваемых им сведений, гносеологически это нейтрально), единство препоручить субстанции, а благо рассматривать совершенно отдельно от истины, в рамках специальной дисциплины - этики. Ведь «практический разум» с истиной как бы не корреспондирует? Регулятивностью обходится? Попробуем представить себе: к Сократу подходит человек с философским вопросом, а он, выслушав, отвечает: это не ко мне, это вопрос по специальности 09.00.01 (онтология, гносеология, феноменология), - это к Пармениду Элейскому.

Единство трансценденталий обеспечивает смыслом человеческое бытие, в том числе и занятия философией. Потому что оно есть гарант смысла вообще, как такового. Философствовать позволительно о чём угодно, хоть о бизнесе, хоть о музыке, хоть о толковании текстов. Думаю, понятно: обеспечить успешными умениями профессиональную деятельность, «техне», подобное умствование не может. Чтобы не стать суесловием, такого рода региональному философствованию стоило бы сказать что-либо вразумительное о смысле той или иной человеческой деятельности.

«Вы смотрите устрицей из раковин вещей» (В. Маяковский). Вотще и всуе остаётся онтологически значимая истина, возвещённая апостолом Павлом, не поленюсь её повторить: что ты имеешь, чего бы не получил, а если получил, что хвалишься, 
что не получил? Вместе со способностью даже и сомневаться? Или всё, что есть, нажито непосильным собственным трудом? Мудрость, в конце концов, предполагает умение признавать факты... Впрочем, Гуссерль всерьёз полагал, что времена философии как мудрости прошли, она уже стала наукой. Это - манифестация одного из догматов «религии науки» (А. И. Герцен), отзвук веры Огюста Конта в то, что «метафизическая» стадия истории человечества позади, что теперь презумпция истинности на стороне науки. В Новое время ось иерархии в умах европейского человечества перевернулась. Если в «тёмные века» дело представлялось так, что богословие царствовало, философия ему услужала, а наука вообее прозябала в подмастерьях, то отныне всё с точностью до наоборот: наука правит, а религию пытаются щадить и терпеть признанием за ней некоего наукообразия (это особенно характерно для англо-американской «философии религии»). Что осталось неизменным, так это статус философии, - ей по старинке предписано служить, но уже новому хозяину - науке. С. Н. Булгаков полагал, что, как служанка, философия вере не нужна. Дорога как сестра. Следует только понять, что отношения господстваподчинения не столь универсальны, чтобы видеть в них ключ к пониманию истины.

Нет никакой возможности ответить на каждый из аргументов А. Богачёва. Большей частью, дело сводится к неприятию христианства да и религии вообще. Поэтому, как мог, я ограничивался самыми принципиальными вопросами. Да и скучновато пересказывать контраргументацию против язычников, накопившуюся за двадцать веков православия. И малопродуктивно. Доказательство есть форма принуждения, а вера - акт свободы.

Весьма ощутим европоцентризм автора - архаика, обретшая второе дыхание у младоевропейцев. Православие видится им окаменелостью времён докембрия, символом невежества. Потому и контраргументация с позиций самоновейшей науки представляется, наверное, убийственной. Понятно, это от поверхностного знакомства с трудами Отцов Церкви. Между прочим, ещё в четвёртом веке Василий Великий в «Шестодневе» упоминал о шарообразности Земли. В то время когда древние рассказывли о китах и слонах, Библия говорит, что Бог «повесил землю ни на чём» (Иов 26:7). Православная церковь, в отличие от западной, с наукой не воевала, костров инквизиции не разжигала. Потому и извиняться задним числом перед Бруно и Галилеем ей не приходится.

Для А. Богачёва не подлежит сомнению, что я есть олицетворение и завершение русской религиозно-философской традиции (с. 193). Не знаю, достоин ли я стать в один ряд с Соловьёвым, Булгаковым и Зеньковским (кстати, какое-то время нашей кафедрой заведовал), автору виднее. Как бы и лестная квалификация, да есть подтекст: богачёвская оценка этой традиции, по всему чувствуется, мало чем отличается от одиозной шпетовской. У Густава Шпета, наверное, и одолжена.

Есть и недоразумение: Православие, как и христианство в целом, весьма опрометчиво трактовать в духе этноцентризма и национализма. Разделение христиан по этническому признаку (да и вообще всякое их разъединение) Церковь давным-давно осудила как ересь филетизма. Хотел бы я видеть отделение польских или французских католиков от Ватикана! У Бога нет отдельного рая для украинцев и русских, все Христу одинаково дороги. И если я говорю о «метафизике православной догматики», то нет оснований отождествлять эту идею с русской религиознофилософской мыслью (впрочем, мотивы А. Богачёва, мне кажется, понятны). Я вовсе не отказываюсь быть русским, но надо же отдавать себе отчёт, как много 
ценного внесли в сокровищницу православной мысли греки, сербы, румыны, православные разной прописки.

Не вина, а беда русской религиозной философии состояла, на мой взгляд, в том, что она пыталась говорить о своём языком «философии субъекта». Заимствованным. И потому многое сказано невнятно. Так что работы ещё непочатый край, и хоронить традицию рановато.

\section{СПИСОК ЛИТЕРАТУРЫ}

Антоний Сурожский, митрополит. Школа молитвы: Сборник. - Николаев: Літопис, 2009. $432 \mathrm{c}$.

Андреев И. М. Православная апологетика. - М.: Сретенский монастырь, 2006. - 192 с.

Богачев A. Sacrificum intellectus, або ж Нове обличчя догматизму // Sententiae. - vol. XXIX. 2013. - № 2. - C. 193-203.

Вениамин (Новик), игумен. О православно-христианском миропонимании // Электронный peсурс. Режим доступа: http://philosophy.ru/library/novik/ponim.html

Зізіулас Йоан, митрополит. Буття як спілкування. Дослідження особистісності і Церкви. К.: Дух і літера, 2005. - 276 с.

Иустин (Попович) Путь Богопознания // Иустин (Попович) Собр. Творений. - М.: Паломник, 2004. - Т. 1. -432 с.

Соловьёв В. С. Кризис западной философии // Соловьёв В.С. Соч. в 15 т. 2-е изд. - СПб.: Просвещение. - Б. г. - Т. 1. - 384 с.

Яннарас X. Вера Церкви. - М.: Центр по изучению религий, 1992. - 231 с.

Стаття одержана редакцією 21.01.2014

\section{Vladimir Demyanov}

\section{Dogmatism forever, nothing new}

This article is an answer to the article by Andriy Bogachov "Sacrificium intellectus. A representation of modern dogmatism". The author, trying to abstract as far as possible from a personal context, attempts to argue for the legitimacy of Christian metaphysics in contemporary philosophy. The field of discourse is outlined by the distinction between the concepts "knowledge/faith" and "subject/personality (hypostasis)". The key question is ontological priority of a personal modus of being over individual-subjective modus, and, respectively, faith as a condition of a possibility of knowledge and human image of being, since human being is portrayed here as a being that knows itself, as an identity of being and knowledge.

Vladimir Demyanov, PhD in Philosophy, Associate professor of the Philosophy Department, Taras Shevchenko National University of Kyiv

Володимир Дем'янов, кандидат філософських наук, дочент кафедри філософії Київського начіонального університету імені Тараса Шевченка

Владимир Демьянов, кандидат философских наук, дочент кафедры философии Киевского национального университета имени Тараса Шевченко 